\title{
Reverse transcriptase activity associated with haemic neoplasia in the soft-shell clam Mya arenaria
}

\author{
M. AboElkhair ${ }^{1}$, A. Siah ${ }^{1}$, K. F. Clark ${ }^{2}$, P. McKenna ${ }^{1}$, J. Pariseau ${ }^{1,3}$, \\ S. J. Greenwood ${ }^{1,2}$, F. C. J. Berthe ${ }^{4}$, A. Cepica ${ }^{1, *}$ \\ ${ }^{1}$ Department of Pathology and Microbiology, Atlantic Veterinary College, University of Prince Edward Island, \\ Charlottetown, Prince Edward Island C1A 4P3, Canada \\ ${ }^{2}$ AVC Lobster Science Centre, Atlantic Veterinary College, University of Prince Edward Island, Charlottetown, \\ Prince Edward Island C1A 4P3, Canada \\ ${ }^{3}$ Institut des Sciences de la mer, Université du Québec à Rimouski, Rimouski, Québec G5L 3A1, Canada \\ ${ }^{4}$ European Food Safety Authority (EFSA), Animal Health and Welfare Panel, 43100 Parma, PR, Italy
}

\begin{abstract}
Reverse transcriptase (RT) activity has been reported in bivalves affected by haemic neoplasia (HN). Since all retroviruses have RT, detection of RT activity was regarded as evidence for the retroviral etiology of HN. This study investigates the relationship between RT levels and the progress of HN as indicated by percentages of tetraploid cells in soft-shell clams Mya arenaria. The percentages of tetraploid cells were estimated by flow cytometry, and the RT levels were quantified using TaqMan product-enhanced RT (TM-PERT) assay. Results demonstrated that the amount of RT was positively correlated with the percentage of tetraploid cells circulating in clam haemolymph $\left(\mathrm{R}^{2}=\right.$ $0.974, \mathrm{p}<0.001)$. Compared to HN-negative clams (<5\% tetraploid cells), 2 stages with significantly elevated levels of RT activity were observed: the first stage at $\sim 10$ to $\sim 20 \%$ tetraploid cells, and the second at $\sim 30$ to $\sim 80 \%$ tetraploid cells ( $p<0.01$ ). These data support the well established fact from mammalian models that transformed cells express high levels of non-telomeric RT. The observed increase in RT levels at $\sim 30 \%$ tetraploidy coincides with previously reported p53 gene expression. Taken together, this could indicate that using RT levels as an indicator of $H N, \geq 30 \%$ tetraploidy is the stage at which the disease process undergoes a change, and perhaps becomes irreversible.
\end{abstract}

KEY WORDS: Mya arenaria · Haemic neoplasia · Reverse transcriptase · Polyploidy · TaqMan · Product-enhanced reverse transcriptase assay $\cdot$ PERT

\section{INTRODUCTION}

Haemic neoplasia (HN) is a leukemia-like disease of the soft-shell clam Mya arenaria. The condition is often fatal and progressive in most of the locations where the disease has been reported (Barber 2004). In Prince Edward Island (PEI), Canada, massive mortalities of soft-shell clams were linked to high prevalence of HN (McGladdery et al. 2001). Different diagnostic techniques for the detection of HN based on the morphological distinction between normal and neoplastic haemocytes have been employed (Elston et al. 1992, McGladdery et al. 2001, Barber 2004). Neoplastic cells have large pleomorphic nuclei containing one or more nucleoli, with higher nucleo-cytoplasmic ratios. Given the change in ploidy of circulating haemocytes in diseased individuals, DNA content measurement using flow cytometry (FCM) has increasingly become a powerful tool for diagnosis of HN in bivalves (Harper et al. 1994, Reno et al. 1994, da Silva et al. 2005, Delaporte et al. 2008). The ploidy status in HN has been shown to vary among bivalve species. In Mya arenaria, HN 
affected individuals have been found to show tetraploid cells with 1.25 to 2.05 times more DNA than normal diploid haemocytes (Reno et al. 1994).

Since the initial description of the disease (Farley 1969), its cause has not been clearly defined (Barber 2004). Viral infection, genetic profile, environmental changes and anthropogenic pollution have been proposed as the causative factors (Elston et al. 1992, McGladdery et al. 2001, Barber 2004). Retroviral etiology, in particular, has been suggested by several authors (Oprandy et al. 1981, Oprandy \& Chang 1983, Romalde et al. 2007). The main evidence supporting a retroviral etiology of $\mathrm{HN}$ has been the detection of reverse transcriptase (RT) activity in individuals affected by this pathological condition in soft-shell clams (Medina et al. 1993, House et al. 1998) and in cockles, Cerastoderma edule (Romalde et al. 2007). Reverse transcriptase activity, however, is not exclusive to retroviruses. Other viruses (hepadnaviruses), some bacteria (e.g. strains of Myxobacteria and Escherichia coli), and also telomerases (a set of enzymes that lengthen the chromosome end (telomere) by reverse transcription of its own RNA; Flint et al. 2004) have RT activity. Moreover, RT-related sequences are found in cellular genomes generally known as retroelements (Flint et al. 2004). Expression of these endogenous cellular RT-coding genes is repressed in normal terminally differentiated cells, but can be active in tissues with rapidly dividing cells such as germ cells, embryos, and tumors (Spadafora 2004).

The main contention of this study is that the absence of conclusive evidence of an exogenous retrovirus in the presence of RT activity likely means that the RT detected in HN is expressed from sources other than exogenous retrovirus. Thus, quantification of RT activity at different stages of HN development may provide valuable information on possible sources of RT activity. Product-enhanced RT (PERT) assay has been used as a method for general detection of RT activity of both known and unknown retroviruses, which was subsequently modified as TaqMan PERT (TM-PERT). TM-PERT is a quantitative assay in which the resulting cDNA from RT activity is amplified and quantified by fluorogenic 5'-nuclease TaqMan PCR (André et al. 2000, Maudru \& Peden 1998). The use of TM-PERT for quantitative detection of RT activity can help to distinguish the background RT signals arising from nonRT sources, such as some thermostable DNA polymerases released from lysed cells. Also, unlike conventional PERT, TM-PERT detects manganeseand magnesium-dependent RT with approximately equal sensitivity (Maudru \& Peden 1998). Finally, the TM-PERT method allows quantification of RT activity over a wider range of activities than PERT does (Maudru \& Peden 1998).
This study describes the relationship between RT levels and the progress of $\mathrm{HN}$ as indicated by the percentage of tetraploidy in circulating haemocytes from soft-shell clams.

\section{MATERIALS AND METHODS}

Samples. Two hundred clams were collected from North River $\left(46^{\circ} 15^{\prime} 01^{\prime \prime} \mathrm{N}, 63^{\circ} 10^{\prime} 42^{\prime \prime} \mathrm{W}\right)$, Charlottetown, PEI, Canada in October 2007. Following gradual acclimation from 5 to $18^{\circ} \mathrm{C}$ over $2 \mathrm{~d}$, the clams were held in tanks at $18^{\circ} \mathrm{C}$ until use.

Flow cytometry. The FCM procedure was performed according to Delaporte et al. (2008). Briefly, haemolymph was withdrawn from the anterior adductor muscle of each clam using a 25-gauge needle fitted with a $3 \mathrm{ml}$ syringe. A $0.5 \mathrm{ml}$ haemolymph sample was fixed in $2.5 \mathrm{ml}$ of $95 \%$ cold ethanol. After centrifugation at $400 \times g$ for $10 \mathrm{~min}$, cell pellets were resuspended and rehydrated in phosphate buffered saline (PBS, $0.01 \mathrm{M}$ ) for $30 \mathrm{~min}$, followed by 2 washes in PBS (0.01M). The resuspended filtered cell pellets were treated with DNase-free RNase A (Sigma, R4875, $50 \mu \mathrm{g} \mathrm{ml}^{-1}$ ) and stained with propidium iodide (PI, Sigma, P4170, $50 \mu \mathrm{g}$ $\mathrm{ml}^{-1}$ ). A specific FL2 detector (orange light, at a wavelength of 550 to $600 \mathrm{~nm}$ ) of a FACSCalibur flow cytometer (BD BioSciences) was used to measure fluorescence of PI-stained cells. For each sample, 10000 particles were counted at a low flow rate $\left(15 \mu \mathrm{min}^{-1}\right)$. For each cell, a single electronic pulse of PI fluorescence was recorded. Each pulse was discriminated by its area, height and width. Based on these data, the tetraploid cells at the G2/M phase were distinguished from normal diploid cells $(2 \mathrm{~N})$ at the G0/G1 phase, and from doublets of diploid cells (2 cells with the same DNA quantity (2N) stuck together) by plotting FL2-area vs. FL2-width on cytograms (Fig. 1a). To discriminate single cells from doublets, the R1 region was drawn on data scatter plots so that cell doublets were plotted to the right of R1 (Fig 1a). Also, PI fluorescence intensities of single cells were plotted on an FL2-area histogram in order to calculate the percentage of normal cells and tetraploid cells in the tested sample (Fig. 1b).

Quantification of RT activity. Samples: After individual assessment of all clams by FCM, clams were assigned to 1 of 7 groups based on the percentages of tetraploid cells in the haemolymph, for TM-PERT analysis (Table 1). Clams with $<5 \%$ tetraploid cells were considered as HN-negative controls based on Delaporte et al. (2008). Three clams were selected for inclusion in each of the 6 subsequent groups, except the $\sim 70 \%$ group, which contained only 2 clams. The detailed composition of the experimental groups and the percentages of tetraploid cells in clams are listed in 

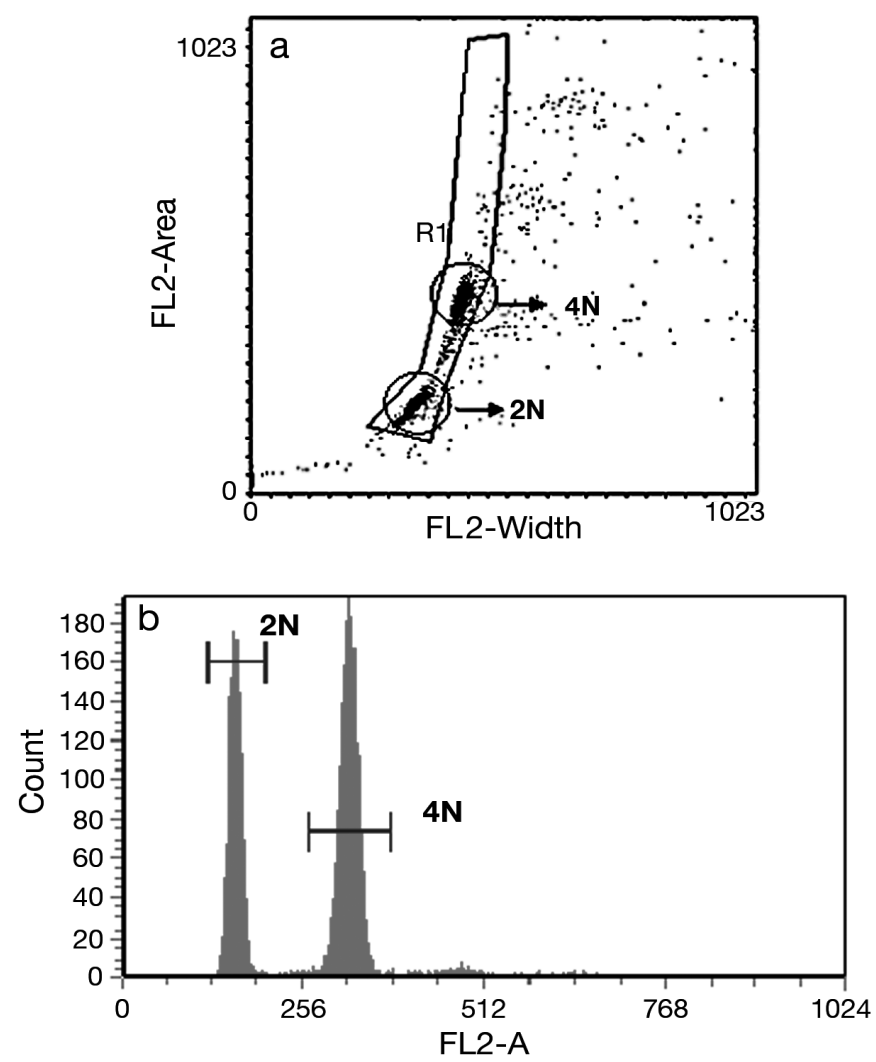

Fig. 1. Mya arenaria. Analysis of propidium iodide (PI)stained clam haemocyte DNA contents (FL2) by flow cytometry. (a) Diploid and tetraploid single cells gated in R1 on an FL2-width versus FL2-area cytogram. (b) PI fluorescence of single cells in R1 plotted on an FL2-area histogram. Diploid $(2 \mathrm{~N})$ and tetraploid $(4 \mathrm{~N})$ peaks are delimited by markers. For further definitions see 'Materials and methods'

Table 1. Clams containing between $>5 \%$ and $<20 \%$ tetraploid cells were presumed doubtful, and those with $>20 \%$ tetraploid cells were presumed positive based on Delaporte et al. (2008).

Preparation of samples: From each selected individual, $1 \mathrm{ml}$ of haemolymph was withdrawn from the anterior adductor muscle as described above. The haemolymph samples were centrifuged at $500 \times g$ for $15 \mathrm{~min}$, and supernatants were again centrifuged at $13400 \times g$ for $5 \mathrm{~min}$. Supernatants were then passed through $0.22 \mu \mathrm{m}$ filters (VWR International), aliquoted, and stored at $-80^{\circ} \mathrm{C}$.

TM-PERT assay: Assay conditions, and primer and probe sequences, were adopted from Maudru \& Peden (1998) with some modifications. The respective sequences of primers A and B were 5'-GCC TTA GCA GTG CCC TGT CT-3' and 5'-AAC ATG CTC GAG GGC CTT A-3', while that of the probe was FAM-5'CCC GTG GGA TGC TCC TAC ATG TC-3'-BHQ1.

For reverse transcription, $0.4 \mu \mathrm{g}$ of the bacteriophage MS2 genomic RNA template (Roche Applied Science)
Table 1. Mya arenaria. Percentages of tetraploidy and group classification for selected individuals assayed using the TaqMan product-enhanced reverse transcriptase (TM-PERT) assay

\begin{tabular}{|lcc|}
\hline $\begin{array}{l}\text { Groups } \\
\text { (\% tetraploid cells) }\end{array}$ & $\%$ tetraploidy & No. of animals \\
\hline Negative group & $1.1,2.0,2.2$ & 3 \\
$\sim 10$ & $11.8,9.7,12.0$ & 3 \\
$\sim 20$ & $19.3,21.3,26.9$ & 3 \\
$\sim 30$ & $30.0,30.0,30.0$ & 3 \\
$\sim 50$ & $55.0,61.3,53.8$ & 3 \\
$\sim 70$ & $74.8,74.6$ & 2 \\
$\sim 80$ & $80.0,80.0,94.0$ & 3 \\
\hline
\end{tabular}

was mixed with $5 \mu \mathrm{M}$ of primer A in RNase-free water, in a final volume of $2 \mu \mathrm{l}$ per $\mathrm{RT}$ reaction. The mixture was heated at $85^{\circ} \mathrm{C}$ for $5 \mathrm{~min}$, annealed at $37^{\circ} \mathrm{C}$ for $30 \mathrm{~min}$, and kept at $4^{\circ} \mathrm{C}$ for $5 \mathrm{~min}$. Then, $2 \mu \mathrm{l}$ of clam haemolymph sample was added to the $\mathrm{RT}$ reaction mixture containing $50 \mathrm{mM}$ Tris- $\mathrm{HCl}$, $8 \mathrm{mM} \mathrm{MgCl}_{2}$, $30 \mathrm{mM} \mathrm{KCl}, 1 \mathrm{mM}$ dithioerythritol, $10 \mathrm{U}$ RNAsin (Promega), and $1 \mathrm{mM}$ dNTPs (Qiagen), to give a $20 \mu \mathrm{l}$ final volume. The reaction was then incubated at $37^{\circ} \mathrm{C}$ for $1 \mathrm{~h}$, then at $95^{\circ} \mathrm{C}$ for $7 \mathrm{~min}$.

For PCR amplification, $5 \mu$ of the synthesized cDNA was added to the PCR reaction mixture to give a total volume of $25 \mu \mathrm{l}$. The reaction mixture included $1 \times$ TaqMan Universal Master Mix including AmpErase uracilN-glycosylase (UNG) (Applied Biosystems), $0.3 \mu \mathrm{M}$ of primer $\mathrm{A}, 0.3 \mu \mathrm{M}$ of primer $\mathrm{B}, 0.15 \mu \mathrm{M}$ of probe labeled at the $3^{\prime}$ end with FAM and at the 5' end with Black Hole Quencher (BHQ) 1 (Biosearch Technologies), and $250 \mathrm{ng}$ of RNase A (Qiagen). The tubes were placed in the Chromo 4 system (Bio-RAD), and incubations were controlled using MJ Opticon Monitor version 3.1 with the following thermal cycler conditions: $37^{\circ} \mathrm{C}$ for $15 \mathrm{~min} ; 50^{\circ} \mathrm{C}$ for $2 \mathrm{~min} ; 95^{\circ} \mathrm{C}$ for $10 \mathrm{~min} ; 45$ cycles at $95^{\circ} \mathrm{C}$ for $15 \mathrm{~s}, 56^{\circ} \mathrm{C}$ for $15 \mathrm{~s}$, and $72^{\circ} \mathrm{C}$ for $30 \mathrm{~s}$. A standard curve was established by using a 10-fold dilution of Moloney murine leukemia virus (M-MLV) RT (Roche Applied Science) from $10^{2}$ to $10^{10}$ picounits (pU). The enzyme was diluted in buffer A consisting of $50 \mathrm{mM} \mathrm{KCl}, 20 \mathrm{mM}$ Tris- $\mathrm{HCl} \mathrm{pH}$ 7.5, $0.2 \mathrm{mM}$ dithiothreitol, 0.25 mM EDTA, $0.025 \%$ Triton X-100 (v/v), and $50 \%$ glycerol $(\mathrm{v} / \mathrm{v})$. The amplified PCR products of the serial dilutions were resolved by $1.5 \%$ agarose gel electrophoresis in $1 \times$ tris-borate-EDTA (TBE) buffer, visualized by staining with ethidium bromide, and photographed using UV illumination.

Electron microscopy. Haemolymph samples from clams $(n=10)$ previously classified by FCM to be between 8 and $70 \%$ tetraploid, were analyzed by electron microscopy (EM) in order to explore the presence of retroviral particles. Haemolymph samples were fil- 
tered using a $0.45 \mu \mathrm{m}$ syringe filter (VWR International), and centrifuged at $100000 \times g$ for $90 \mathrm{~min}$ in an SW 60 Ti rotor (Beckman). Each resultant pellet was resuspended in $30 \mu \mathrm{l}$ TNE buffer $(10 \mathrm{mM}$ Tris $\mathrm{pH}$ 7.4, $400 \mathrm{mM} \mathrm{NaCl}$ and $1 \mathrm{mM}$ EDTA; Oprandy et al. 1981). Volumes of $10 \mu \mathrm{l}$ were placed on Formvar-coated grids and allowed to dry. One drop of a mixture of phosphotungstic acid and bovine serum albumin was placed on the grid and the excess was blotted off with filter paper. The samples were examined with a Hitachi H7500 electron microscope (Nissei Sangyo) at $80 \mathrm{kV}$.

Data analysis. A linear regression line between the logarithms of the RT standards and the corresponding threshold cycle $\left(C_{\mathrm{T}}\right)$ values was calculated and plotted. The logarithms of RT levels in haemolymph samples were determined by extrapolating the $C_{\mathrm{T}}$ values from the standard curve. One-way ANOVA was performed to assess multiple comparisons of log RT concentrations among different tetraploidy groups using Minitab software version 15 (Minitab). STATA software version 9 (College Station, Texas, USA) was used for exponential regression analysis. The Gompertz model was used to assess correlation between \% tetraploidy and $\log$ RT concentrations.

\section{RESULTS}

The FCM analysis showed that $116(58 \%)$ clams were negative $(<5 \%$ tetraploid cells), $42(21 \%)$ were diseased $(>20 \%$ tetraploid cells), 20 contained between 20 to $50 \%$ tetraploid cells, and 22 contained $>50 \%$ tetraploid cells.

TM-PERT assay optimization enabled the detection of up to $10^{2} \mathrm{pU}$ of RT $2 \mathrm{\mu l}^{-1}$ of haemolymph or $5 \times$ $10^{4} \mathrm{pU} \mathrm{ml}^{-1}$, which is equivalent to 50 retroviral particles $\mathrm{ml}^{-1}$ (a retrovirus particle contains $\sim 10^{3} \mathrm{RT} \mathrm{pU}$ ) (Maudru \&Peden 1998). The M-MLV RT standard curve showed a linear relationship between threshold cycle and the log of RT concentrations over a wide range of concentrations $\left(10^{2}\right.$ to $10^{10} \mathrm{pU}$ ) (Fig. 2a). The numerical means and SD values of the slopes, the $y$ intercepts, and the $\mathrm{R}^{2}$ of the assays performed were $-3.631 \pm 0.217,46.64 \pm 3.16$, and $0.9965 \pm 0.00214$, respectively. The PCR product target specificity of TMPERT assay was verified by agarose gel electrophoresis, which revealed a band of the expected size (112 bp). In addition, negative controls with no RT source, which were replaced with either RNase-free water or buffer A, showed no bands (Fig. 2b).

One of the HN-negative haemolymph samples used for quantitative assessment of RT activity exhibited no signal; the other 2 ind. showed $C_{\mathrm{T}}$ values of 34.31 and 39.58, respectively. The logarithms of RT levels in individuals with $\sim 10$ to $\sim 80 \%$ tetraploid cells ranged from
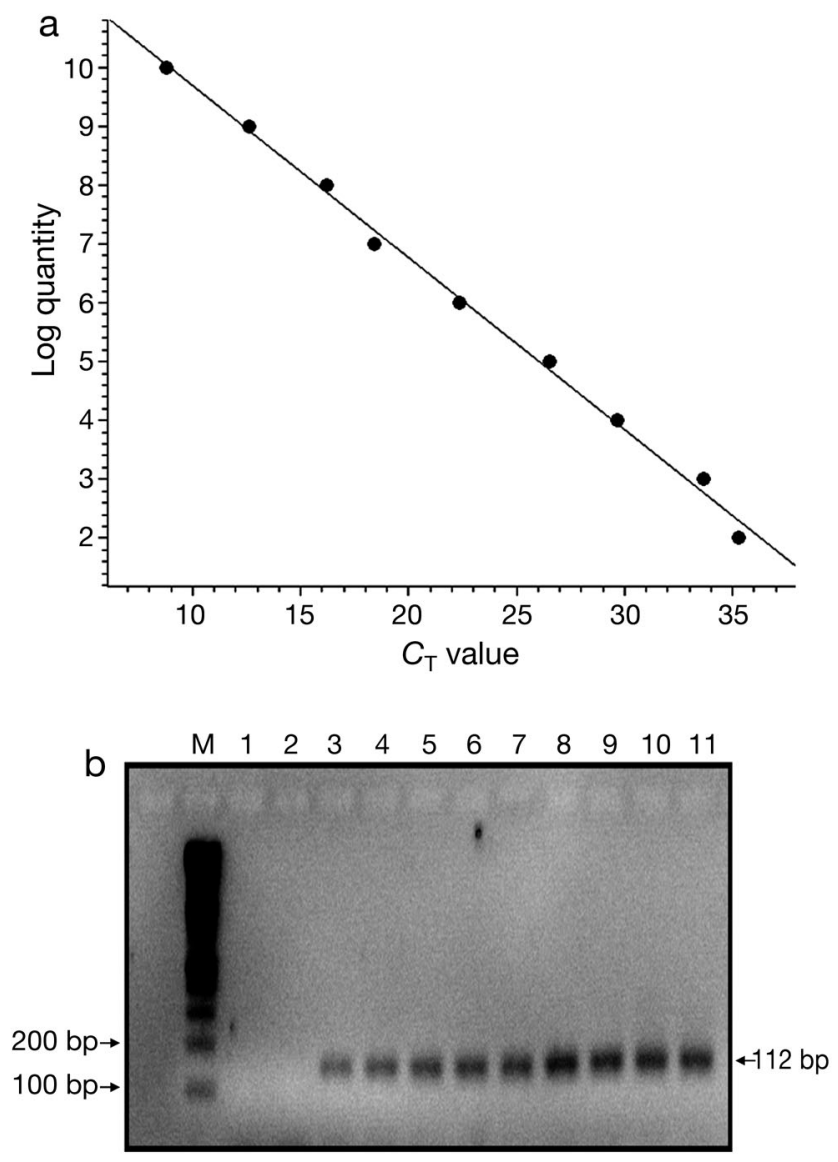

Fig. 2. (a) Standard curve $\left(y=-3.4043 x+43.034 ; R^{2}=0.9989\right)$ of TaqMan product-enhanced reverse transcriptase (TMPERT) assay with the serial dilutions of the Moloney murine leukemia virus (M-MLV) reverse transcriptase (RT) from $10^{10}$ to $10^{2} \mathrm{pU}$. (b) Gel electrophoresis of PCR products of TM-PERT assay standard curve reactions. Lanes: 1 , negative control (no RT); 2, negative control (buffer A); 3 to 11, 10-fold dilution of M-MLV RT from $10^{2}$ to $10^{10} \mathrm{pU}$. M: molecular weight marker (100 bp; Roche Applied Science), $C_{\mathrm{T}}$ : threshold cycle number

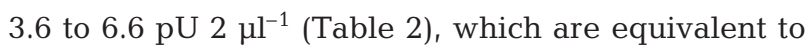
$2 \times 10^{6}$ to $2 \times 10^{9} \mathrm{pU} \mathrm{ml}^{-1}$ of haemolymph, respectively. Compared to the HN-negative group, a significant increase in RT levels was observed in clams with $\sim 10$ and $\sim 20 \%$ tetraploidy, with no significant difference in RT levels between the 2 groups. Further significant increase in RT levels was observed in the haemolymph of clams with $\sim 30 \%$ tetraploid cells and above ( $\mathrm{p}<$ 0.01) (Table 2). Under the conditions of this study, clams could be classified into 3 distinct groups according to the RT levels: $<5 \%$ tetraploid cells; $\sim 10$ to $\sim 20 \%$ tetraploid cells; and $\sim 30$ to $\sim 80 \%$ tetraploid cells. Overall, there was a significant positive correlation between the percentages of tetraploidy and RT levels $\left(R^{2}=0.974, p<0.001\right)$ (Fig. 3). 
Table 2. Mya arenaria. $C_{\mathrm{T}}$ values (mean $\pm \mathrm{SD}$ ) and log of reverse transcriptase (RT) concentrations (mean $\pm \mathrm{SD}$ ) at various percentages of tetraploidy

\begin{tabular}{|c|c|c|}
\hline$\%$ tetraploid cells & $C_{\mathrm{T}}$ values & $\begin{array}{c}\text { Log RT } \\
\text { (pU } 2 \mu \mathrm{l}^{-1} \text { haemolymph) }\end{array}$ \\
\hline Negative group & 0.00 or $>34$ & $1.73 \pm 1.64$ \\
\hline$\sim 10$ & $30.53 \pm 2.74$ & $4.38 \pm 0.77^{\mathrm{a}}$ \\
\hline$\sim 20$ & $30.63 \pm 2.02$ & $4.35 \pm 0.56^{\mathrm{a}}$ \\
\hline$\sim 30$ & $26.32 \pm 0.71$ & $5.55 \pm 0.20^{\mathrm{b}}$ \\
\hline$\sim 50$ & $25.93 \pm 0.53$ & $5.66 \pm 0.15^{b}$ \\
\hline$\sim 70$ & $24.75 \pm 0.96$ & $5.99 \pm 0.27^{b}$ \\
\hline$\sim 80$ & $23.85 \pm 1.05$ & $6.25 \pm 0.29^{b}$ \\
\hline \multicolumn{3}{|c|}{$\begin{array}{l}\text { a Statistically different from the negative group }(p<0.01) \\
{ }^{b} \text { Statistically different from the negative, the } \sim 10 \% \text {, and the } \sim 20 \% \text { groups } \\
(p<0.01)\end{array}$} \\
\hline
\end{tabular}

Apart from retroviruses, there are several other possible sources of RT activity. At the level of the assay itself, there are some reagents that may produce RT-like activity such as Taq DNA polymerases or RNase inhibitors (Pyra et al. 1994). At the level of the tested sample, there are some enzymes that may display RT-like activity such as host DNA polymerases, some other nuclear enzymes, and polymerase from mitochondria (Brorson et al. 2002).

In this study, in order to measure introduction of RT activity from reagents, negative controls with water and buffer A were always included. As a further control to measure possible contribution of sampleunrelated RT activity arising from PCR reagents, an RNA digestion step with RNase A was included before PCR amplification (Maudru \& Peden 1997). In order to avoid false positive results possibly arising from released cellular enzymes, haemocytes were carefully removed from haemolymph samples by low speed centrifugation, and the assays were performed on a cell free haemolymph.

Although it could be argued that telomerase activity could be present since $\mathrm{HN}$ is widely believed to involve cell transformation, our assay should not have detected telomerase activity for 2 reasons. Firstly, telomerases are template specific, requiring a specific recognition sequence, TTAGGG. Thus, it is generally believed that they are unlikely to reverse transcribe MS2 phage RNA which lacks this target sequence (Brorson et al. 2002). Secondly, the assay was performed on cell free haemolymph as discussed above. On the other hand, TM-PERT is able to detect RT activity of endogenous retroviruses and other retroelements such as retrotransposons (Brorson et al. 2002).

Our detection of low levels of RT activity in some disease-negative clams is in agreement with findings in other species: e.g. in turtles (Casey et al. 1997), humans (Molès et al. 2007), and cockles (Romalde et al. 2007). The observed RT activity in HN-negative clams could be related to the fact that RT activity is associated with a wide range of biological processes, both physiological and pathological (Spadafora 2004). This is because RT-coding genes are also contained in repeated genomic elements called retroelements, which play an important role in many physiological and pathological cellular processes (Spadafora 2004).

We found a statistically significant difference in RT quantities between groups with $\sim 10$ to $20 \%$ tetraploid cells and $\sim 30$ to $\sim 80 \%$ tetraploid cells $(\mathrm{p}<0.01$ ) (Table 2). This supports previously published obser- 
vations of disease remission in clams (Cooper et al. 1982, Leavitt et al. 1994) and mussels (Elston et al. $1988)$ in early stages of the disease $(\sim 20 \%$ neoplastic cells). The increased level of significance at $\sim 30 \%$ tetraploidy suggests that this might be the beginning of the irreversible stage in the progression of the pathological process.

The absence of structures similar to retroviral particles in negatively stained samples of clam haemolymph is in disagreement with Oprandy et al. (1981) but in agreement with House et al. (1998) and other electron microscopic studies reviewed by Elston et al. (1992) and Barber (2004). The elevated levels of RT activity at various levels of tetraploidy without indication of retroviral particles in haemolymph samples as evaluated by electron microscopy suggests that the observed RT activity might be due to the expression of endogenous source of RT. Others demonstrated the presence of RT protein in tissues that were not included in retroviral particles, and they suggested endogenous retroelements as the source (Molès et al. 2007).

The positive correlation between levels of tetraploidy and RT activity suggests that the transformed haemocytes might have a role in the increased level of RT activity. Our suggestion is supported by the growing body of data showing that transformed cells of mammalian origin express high levels of endogenous non-telomeric RT, with the source of the RT being endogenous retroelements (Spadafora 2004, Oricchio et al. 2007). Involvement of endogenous retrovirus in HN of Mya arenaria was previously suggested by Oprandy \& Chang (1983).

Further supporting our contention of an endogenous source of RT is the report that RT-coding genes are generally active in cancer cells (Spadafora 2004). In addition, RT gene activity is up-regulated by a variety of stimuli acting at the genomewide level such as cellular stress, heat shock, genotoxic agents and others (Sciamanna et al. 2005).

In conclusion, we suggest that RT activity associated with $\mathrm{HN}$ might be due to activation of endogenous retroelements, but whether this activity is a consequence, or is related to the cause of the disease requires further investigation. What retroelement may be responsible for production of RT activity is presently unclear. On the other hand, whether or not an exogenous retrovirus plays a role in induction of $\mathrm{HN}$ cannot be conclusively answered by our current data; however, our results on RT activity and EM analysis of haemolymph, combined with observations by other authors (Elston et al. 1992, House et al. 1998, Molés et al. 2007), suggest that the RT activity is not from an exogenous retrovirus.

Compared to HN-negative animals, the 2 significant increases in RT levels - first at $\sim 10$ to $~ 20 \%$ tetraploid cells and second at $\sim 30$ to $\sim 80 \%$ tetraploid cells - suggest that the stage from $\leq 10$ to $\geq 30 \%$ tetraploid cells should be targeted for further investigations on the mechanism of induction of HN.

Acknowledgements. We thank J. W. Casey for his helpful advice, G. Johnson for his valuable support of this study, and A. Mounchili for his help in statistical analysis. The research was supported by the Egyptian Cultural and Educational Bureau in Montréal, Quebec, Canada.

\section{LITERATURE CITED}

André M, Morgeaux S, Fuchs F (2000) Quantitative detection of RT activity by PERT assay: feasibility and limits to a standardized screening assay for human vaccines. Biologicals 28:67-80

Barber BJ (2004) Neoplastic diseases of commercially important marine bivalves. Aquat Living Resour 17:449-466

Brorson K, Xu Y, Swann PG, Hamilton E and others (2002) Evaluation of a quantitative product-enhanced reverse transcriptase assay to monitor retrovirus in mAb cellculture. Biologicals 30:15-26

Casey RN, Quackenbush SL, Work TM, Balazs GH, Bowser PR, Casey JW (1997) Evidence for retrovirus infections in green turtles Chelonia mydas from the Hawaiian Islands. Dis Aquat Org 31:1-7

Cooper KR, Brown RS, Chang PW (1982) The course and mortality of a hematopoietic neoplasm in the soft-shell clam Mya arenaria. J Invertebr Pathol 39:149-157

da Silva PM, Soudant P, Carballal MJ, Lambert C, Villalba A (2005) Flow cytometric DNA content analysis of neoplastic cells in haemolymph of the cockle Cerastoderma edule. Dis Aquat Org 67:133-139

Delaporte M, Synard S, Pariseau J, McKenna P, Tremblay R, Davidson J, Berthe FCJ (2008) Assessment of haemic neoplasia in different soft shell clam Mya arenaria populations from eastern Canada by flow cytometry. J Invertebr Pathol 98:190-197

Elston RA, Kent ML, Drum AS (1988) Progression, lethality and remission of hemic neoplasia in the bay mussel Mytilus edulis. Dis Aquat Org 4:135-142

Elston RA, Moore JD, Brooks K (1992) Disseminated neoplasia of bivalve molluscs. Rev Aquat Sci 6:405-466

Farley CA (1969) Probable neoplastic disease of the hematopoietic system in oysters Crassostrea virginica and Crassostrea gigas. Natl Cancer Inst Monogr 31:541-555

Flint SJ, Enquist LW, Racaniello VR, Skalka AM (2004) Principles of virology: molecular biology, pathogenesis and control of animal viruses, 2nd edn. ASM Press, Washington, DC, p 217-230

> Harper DM, Flessas DA, Reinisch CL (1994) Specific reactivity of leukemia cells to polyclonal anti-PCB antibodies. J Invertebr Pathol 64:234-237

> House ML, Kim CH, Reno PW (1998) Soft-shell clams Mya arenaria with disseminated neoplasia demonstrate reverse transcriptase activity. Dis Aquat Org 34:187-192

Leavitt DF, Miosky Dragos D, Lancaster BA, Craig AC, Reinisch CL, Capuzzo JM (1994) Initiation and promotion of hematopoietic neoplasia in soft shells, Mya arenaria, exposed to natural sediment. In: Rosenfield A, Kern FG, Keller BJ (eds) Proc Int Workshop on Invertebrate Neoplasia: initiation and promotion mechanisms. June 23, 1992, Washington, DC, p 23-25 
Maudru T, Peden K (1997) Elimination of background signals in a modified polymerase chain reaction-based reverse transcriptase assay. J Virol Methods 66:247-261

Maudru T, Peden K (1998) Adaptation of the fluorogenic 5'nuclease chemistry to a PCR-based reverse transcriptase assay. Biotechniques 25:972-975

McGladdery SE, Reinisch CL, MacCallum GS, Stephens RE, Walker CL, Davidson JT (2001) Haemic neoplasia in softshell clams Mya arenaria: recent outbreaks in Atlantic Canada and discovery of a p53 gene homologue associated with the condition. Bull Aquac Assoc Can 101:19-26

Medina DJ, Paquette GE, Sadasiv EC, Chang PW (1993) Isolation of infectious particles having reverse transcriptase activity and producing hematopoietic neoplasia in Mya arenaria. J Shellfish Res 12:112-113

Molès JP, Tesniere A, Guilhoi JJ (2007) Reverse transcriptase activity in human normal and psoriatic skin samples. Br J Dermatol 157:482-486

Oprandy JJ, Chang PW (1983) 5-bromodeoxyuridine induction of hematopoietic neoplasia and retrovirus activation in softshell clam Mya arenaria. J Invertebr Pathol 42: 196-206

Oprandy JJ, Chang PW, Pronovost AD, Cooper KR, Brown RS, Yates VJ (1981) Isolation of viral agent causing hematopoietic neoplasia in the soft-shell clams Mya arenaria. J Invertebr Pathol 38:45-51

Editorial responsibility: Catherine Collins, Aberdeen, UK
Oricchio E, Sciamanna I, Beraldi R, Tolstonog GV, Schumann GG, Spadafora C (2007) Distinct roles for LINE-1 and HERV-K retroelements in cell proliferation, differentiation and tumor progression. Oncogene 26:4226-4233

Pyra H, Boni J, Schupbach J (1994) Ultrasensitive retrovirus detection by a reverse transcriptase assay based on product enhancement. Proc Natl Acad Sci USA 91:1544-1548

Reno PW, House M, Illingworth A (1994) Flow cytometric and chromosome analysis of softshell clams Mya arenaria with disseminated neoplasia. J Invertebr Pathol 64:163-172

> Romalde JL, Vilarino ML, Beaz R, Rodriguez JM, Diaz S, Villalba A, Carballal MJ (2007) Evidence of retroviral etiology for disseminated neoplasia in cockles (Cerastoderma edule). J Invertebr Pathol 94:95-101

Sciamanna I, Landriscina M, Pittoggi C, Quirino M and others (2005) Inhibition of endogenous reverse transcriptase antagonizes human tumor growth. Oncogene 24: 3923-3931

Siah A, Delaporte M, Pariseau J, McKenna P, Berthe FCJ (2008) Patterns of p53, p73 and mortalin gene expression associated with haemocyte polyploidy in the soft-shell clam Mya arenaria. J Invertebr Pathol 98:148-152

Spadafora C (2004) Endogenous reverse transcriptase: a medi ator of cell proliferation and differentiation. Cytogenet Genome Res 105:346-350

Submitted: August 4, 2008; Accepted: January 25, 2009 Proofs received from author(s): February 26, 2009 